\title{
Experimental evaluation of anticonvulsant effect of human placental extract in pentylenetetrazole induced convulsions in mice
}

\author{
Avanthi S. ${ }^{1}$, Pushpalatha Chinnam ${ }^{1}$, Gundappa S. Rao ${ }^{2}$, \\ Sam Pavan Kumar G. ${ }^{1}$, Mohd. Mohsin ${ }^{1}$
}

\begin{abstract}
${ }^{1}$ Department of Pharmacology, Chalmeda Anand Rao Institute of Medical Sciences, Karimnagar505001, Andhra Pradesh, India ${ }^{2}$ Department of Agada Tantra, Amrita School of Ayurveda, Amrita University, Amritapuri Campus, Kollam-690525, Kerala, India
\end{abstract}

Received: 3 July 2013

Accepted: 21 July 2013

\section{*Correspondence to:}

Dr. Pushpalatha Chinnam,

Email: dr_pushpa@yahoo.com

(C) 2013 S Avanthi et al. This is an open-access article distributed under the terms of the Creative Commons Attribution Non-Commercial License, which permits unrestricted non-commercial use, distribution, and reproduction in any medium, provided the original work is properly cited.

\begin{abstract}
Background: Human placental extract (HPE) is used in different clinical conditions. Human placental extract (HPE), a folklore medicine, prepared from fresh, healthy human placenta has been in use, as single dose therapy in the treatment of epilepsy in some parts of India. Hence, present study was carried out to explore anticonvulsant property of Human placental extract (HPE) in Pentylenetetrazole (PTZ) induced convulsions in albino mice.

Methods: Effects of human placental extract (HPE) (1.0, 1.2 and $1.4 \mathrm{ml} / 100 \mathrm{gm}$ body weight) as test drug, sodium valproate $(150 \mathrm{mg} / \mathrm{kg}$ body weight $)$ as standard and distilled water as control were studied in pentylenetetrazole (PTZ) induced convulsions in albino mouse model. Failure to observe even a single episode of tonic spasm for $5 \mathrm{sec}$. duration for 1 hour was taken as index of anticonvulsant activity. Onset, duration, complete recovery from convulsion and percent protection was calculated and statistical analysis was carried out using student ' $\mathrm{t}$ ' test.

Results: Pretreatment with human placental extract (HPE) administered in the dose of $1.0 \mathrm{ml} / 100 \mathrm{gm}$ body weight provided $33.33 \%$ and in the doses of 1.2 and $1.4 \mathrm{ml} / 100 \mathrm{gm}$ body weight and sodium valproate provided $100 \%$ protection from convulsions induced by Pentylenetetrazole in albino mice.

Conclusion: Human placental extract (HPE) has shown promising anticonvulsant effect on Pentylenetetrazole induced mouse model.
\end{abstract}

Keywords: Anticonvulsant, Human placental extract (HPE), Sodium valproate, Pentylenetetrazole

\section{INTRODUCTION}

Epilepsy is a disorder of brain function characterized by periodic and unpredictable occurrence of seizures. The term Seizure refers to a transient alteration of behavior due to the disordered, synchronous, and rhythmic firing of populations of brain neurons. ${ }^{1}$ Epilepsy is the second most common neurological disorder in India. ${ }^{2,3}$ Standard therapy permits control of seizures in approximately $80 \%$ of these patients. ${ }^{4}$ But even with the best management, optimum seizure control cannot be guaranteed, and the disease remains disabling and stigmatizing. ${ }^{5}$

Although a number of antiepileptic drugs are available, seizures remain uncontrolled in more than $20 \%$ of the patients. Unfavorable responses including drug reactions or poor response to the presently available drugs also indicate a need for development of new drugs or molecules (for treating epileptic seizures) as alternatives. ${ }^{6}$ In this context, the anticonvulsant effect of human placental extract (HPE) was taken up for the study.

Traditional folk medicine makes good use of the flora and fauna of a region, including a number of mineral substances. These herbs and animals are used either whole or in part and made up in either simple or complicated preparations and have proved to be effective therapeutic remedies. Some of these medicinal substances of animal as well as human origin have been quite thoroughly studied with modern scientific methods, and 
their therapeutic properties have been confirmed although not always explained.?

It is known from traditional folk knowledge that the placenta, supporting the baby's growth and development in the mother's womb, contains a wide range of biologically active components. The variety of biological actions of human placental extract (HPE) is a matter of increasing interest. Recent studies revealed that human placental extract (HPE) is a rich source of various bioactive substances like polydeoxyribonucleotides (PDRN), RNA, DNA, peptides, amino acids, enzymes, trace elements, etc. ${ }^{8}$

Human placental extract (HPE) is in use to treat different clinical conditions such as injections for pelvic inflammatory diseases and topical administration in wound healing. Previous studies have shown its antiplatelet, anti-inflammatory, immunomodulating, antioxidant and neuroprotective effect. ${ }^{7}$

In India, besides the use of natural and synthetic medicinal products, some medicines prepared from human parts are employed in curing the diseases. Human placental extract (HPE), a folklore medicine, prepared from fresh, healthy human placenta has been in use as single dose therapy in the treatment of epilepsy in some parts of India. Hence, present study was undertaken to explore anticonvulsant property of Human placental extract (HPE) in Pentylenetetrazole (PTZ) induced convulsions in albino mice.

\section{METHODS}

\section{Animals}

Male albino mice weighing between 25 and 40 grams used for the study were obtained from the central animal house, Chalmeda Anand Rao Institute of Medical Sciences, Karimnagar, AP. The protocol for the study has been approved by Institutional Animal Ethics Committee (IAEC). The experiment was carried out in post graduate laboratory of Pharmacology department.

\section{Chemical}

Pentylenetetrazole (PTZ)

Pentylenetetrazole (Himedia Laboratories Pvt. Ltd., Mumbai, India) was procured from standard suppliers of chemicals.

\section{Drugs}

\section{Sodium valproate}

Sodium valproate (Sun Pharma, Mumbai, India) was purchased from pharmacy.

\section{Human Placental Extract (HPE)}

Human placental extract - Placentrex injection manufactured by Albert David limited, India, was purchased from pharmacy. It is an extract of fresh, term, healthy human placenta tissues. Each $\mathrm{ml}$ of Placentrex is derived from $0.1 \mathrm{gm}$ of fresh human placenta.

\section{Method}

The study was conducted on male albino mice. The chemical method using pentylenetetrazole was employed for comparing the anticonvulsant activity of human placental extract (HPE) with control and standard group of mice. The study was carried out according to the method of H. Gerhard Vogel. ${ }^{9}$

Prior to the experiment, the mice had free access to food and water and were maintained under standard 12 hour light dark cycle. The experiment was carried out at the same time every day (to decrease the variability in epileptic responsiveness from time to time in a day).

Before proceeding with the actual experiment, effective dose of human placental extract (HPE) in pentylenetetrazole induced convulsions in mice had been carried out.

\section{Fixing the effective dose of human placental extract (HPE)}

The dose of the test drug human placental extract (HPE) mentioned in literature is up to $45 \mathrm{ml} / \mathrm{kg}$ body weight (4.5 gm / kg body weight), given intraperitoneally in mice was found to be safe. ${ }^{10}$ As the anticonvulsant dose of human placental extract (HPE) was not known, the study was done to know the effective dose per $100 \mathrm{gm}$ body weight of mouse.

The mice were injected with graded dose increments of human placental extract (HPE). Pairs of mice were administered $0.2,0.4,0.6,0.8,1.0,1.2$ and $1.4 \mathrm{ml} / 100$ gm body weight of test drug (human placental extract) intraperitoneally. After 30 minutes, pentylenetetrazole (PTZ) dissolved in normal saline ${ }^{11}$ was administered at the dose of $60 \mathrm{mg} / \mathrm{kg}$ body weight subcutaneously and observed for one hour for onset, duration and complete recovery from convulsions and also protection from convulsions, were recorded (Table 1). The doses of 1.2 and $1.4 \mathrm{ml} \mathrm{/} 100 \mathrm{gm}$ body weight have shown anticonvulsant effect. The doses 1.0, 1.2 and $1.4 \mathrm{ml} / 100$ gm body weight were chosen for the study.

\section{Experimental procedure}

Thirty male albino mice were divided into 5 groups of 6 each. The mice were marked and kept in separate labeled cages. 
Table 1: Dose response effect of human placental extract (HPE) on pentylenetetrazole induced convulsions on albino mice.

\begin{tabular}{|c|c|c|c|c|c|}
\hline \multirow[b]{2}{*}{ S. No. } & \multirow{2}{*}{$\begin{array}{l}\text { Dose of human } \\
\text { placental extract } \\
\text { (ml } / 100 \text { gm body } \\
\text { weight) }\end{array}$} & \multicolumn{4}{|l|}{ Convulsions } \\
\hline & & $\begin{array}{l}\text { Onset } \\
\text { (sec.) } \\
\text { Mean } \pm \text { SD }\end{array}$ & $\begin{array}{l}\text { Duration } \\
\text { (sec.) } \\
\text { Mean } \pm \text { SD }\end{array}$ & $\begin{array}{l}\text { Recovery } \\
\text { (sec.) } \\
\text { Mean } \pm \text { SD }\end{array}$ & $\%$ Protection \\
\hline 1 & 0.20 & $915 \pm 49.49$ & $54.00 \pm 4.23$ & $835 \pm 17.60$ & $0 \%$ \\
\hline 2 & 0.40 & $950 \pm 70.71$ & $47.50 \pm 3.87$ & $740 \pm 8.94$ & $0 \%$ \\
\hline 3 & 0.60 & $1010 \pm 4.47$ & $41.50 \pm 2.64$ & $685 \pm 8.36$ & $0 \%$ \\
\hline 4 & 0.80 & $1086 \pm 18.64$ & $22.00 \pm 2.44$ & $540 \pm 10.95$ & $0 \%$ \\
\hline 5 & 1.00 & $1190 \pm 24.89$ & $17.50 \pm 2.23$ & $402 \pm 6.36$ & $0 \%$ \\
\hline 6 & 1.20 & - & - & - & $100 \%$ \\
\hline 7 & 1.40 & _ & _ & _ & $100 \%$ \\
\hline
\end{tabular}

$\mathrm{n}=2$ mice in each group

Control: Each mouse was administered $0.5 \mathrm{ml}$ distilled water intraperitoneally.

Standard: Each mouse was administered sodium valproate $150 \mathrm{mg} / \mathrm{kg}$ body weight intraperitoneally. ${ }^{(12)}$

Test - 1 (HPE 1.0): Each mouse was administered human placental extract (HPE) $1.0 \mathrm{ml} / 100$ gm body weight intraperitoneally.

Test - 2 (HPE 1.2): Each mouse was administered human placental extract (HPE) $1.2 \mathrm{ml} / 100$ gm body weight intraperitoneally.

Test - 3 (HPE 1.4): Each mouse was administered human placental extract (HPE) $1.4 \mathrm{ml} / 100$ gm body weight intraperitoneally.

Half an hour after administration of distilled water to control group, sodium valproate to standard group and human placental extract to test groups of mice, pentylenetetrazole (PTZ) $60 \mathrm{mg} / \mathrm{kg}$ body weight was administered subcutaneously over the scruff of the neck and observed for one hour.

The mice were placed in separate cages and were observed for 1 hour. Failure to observe even a single episode of tonic spasm for $5 \mathrm{sec}$. duration for 1 hour was taken as index of anticonvulsant activity. The time taken for the onset, duration and complete recovery from convulsions induced by pentylenetetrazole (PTZ), was recorded. Simultaneously, the number of episodes of convulsions was also recorded.

The results were expressed as Mean \pm SD. The statistical tool, student' $t$ ' test, was used to analyze the data.

\section{RESULTS}

The effect of drugs on mice was observed for one hour after administration of pentylenetetrazole and the readings were recorded.

The mice were observed for onset, duration and recovery from convulsions and percentage protection from convulsions were also recorded and analyzed.

It was observed that all the mice in control group developed convulsions. Human placental extract (HPE) at a dose of $1.0 \mathrm{ml} / 100 \mathrm{gm}$ body weight (Test -1 group) provided $33.33 \%$ protection while at doses 1.2 (Test -2 group) and $1.4 \mathrm{ml} / 100$ gm body weight (Test -3 group) provided $100 \%$ protection from pentylenetetrazole induced convulsions in mice (Table 2).

The mean time of onset of convulsions was increased and time of duration and recovery from convulsion were decreased in $1.0 \mathrm{ml} / 100 \mathrm{gm}$ body weight of human placental extract (HPE) (Test - 1 group) when compared to control group (Table -2$)$ and it was found statistically highly significant $(\mathrm{P}<0.001)$.

The Standard, Test -2 and Test -3 groups of mice did not develop any convulsions.

It was also noted that in Control group one mouse died due to prolonged second episode of convulsion, whereas, no death occurred in other groups. 
Table 2: Effect of human placental extract (HPE) on pentylenetetrazole induced convulsions in albino mice.

\begin{tabular}{|c|c|c|c|c|c|}
\hline \multirow[b]{2}{*}{ S. No. } & \multirow[b]{2}{*}{ Group } & \multicolumn{4}{|l|}{ Convulsions } \\
\hline & & $\begin{array}{l}\text { Onset } \\
\text { (sec.) } \\
\text { Mean } \pm \text { SD }\end{array}$ & $\begin{array}{l}\text { Duration } \\
\text { (sec.) } \\
\text { Mean } \pm \text { SD }\end{array}$ & $\begin{array}{l}\text { Recovery } \\
\text { (sec.) } \\
\text { Mean } \pm \text { SD }\end{array}$ & $\begin{array}{l}\% \\
\text { Protection }\end{array}$ \\
\hline 1 & $\begin{array}{l}\text { Control } \\
\text { Distilled water } \\
0.5 \mathrm{ml} / \text { mouse }\end{array}$ & $882.58 \pm 21.59$ & $58.50 \pm 5.26$ & $860.50 \pm 17.20$ & $0 \%$ \\
\hline 2 & $\begin{array}{l}\text { Standard } \\
\text { Sodium valproate } \\
150 \mathrm{mg} / \mathrm{kg} \text { body weight }\end{array}$ & - & - & - & $100 \%$ \\
\hline 3 & $\begin{array}{l}\text { Test - 1 (HPE 1.0) } \\
\text { Human Placental Extract } \\
1.0 \mathrm{ml} / 100 \text { gm body } \\
\text { weight }\end{array}$ & $1260.60 \pm 16.04^{*}$ & $12.33 \pm 4.30^{*}$ & $360.33 \pm 8.38^{*}$ & $33.33 \%$ \\
\hline 4 & $\begin{array}{l}\text { Test - 2 (HPE 1.2) } \\
\text { Human Placental Extract } \\
1.2 \mathrm{ml} / 100 \text { gm body } \\
\text { weight }\end{array}$ & - & - & - & $100 \%$ \\
\hline 5 & $\begin{array}{l}\text { Test - } 3 \text { (HPE 1.4) } \\
\text { Human Placental Extract } \\
1.4 \mathrm{ml} / 100 \text { gm body } \\
\text { weight }\end{array}$ & - & - & - & $100 \%$ \\
\hline
\end{tabular}

$\mathrm{n}=6$ mice in each group

* $\mathrm{P}<0.001$ Highly significant, when Test group compared with control group.

\section{DISCUSSION}

Pentylenetetrazole is a chemoconvulsant, which induces seizures by the inhibition of $\mathrm{GABA}_{\mathrm{A}}$ receptors and widely accepted experimental model for absence seizure. $^{13,14}$

Administration of sodium valproate completely inhibited pentylenetetrazole induced convulsions and mortality of animals. As an anticonvulsant sodium valproate act by multiple mechanisms, blockade of voltage-dependent sodium channels, augmentation of gamma-aminobutyric acid (GABA)-mediated inhibition. Sodium valproate has been shown to be an effective agent in ameliorating the symptoms of generalized absence seizures via blockade of voltage dependent t-type calcium channels. Thus, our results are in consonance with previous reports and sodium valproate served as a standard control in the present study.

The experiment was carried out in two stages in the laboratory. Initially, the dose response was studied with human placental extract (HPE) to fix the effective anticonvulsant dose and later anticonvulsant effect of three doses (1.0, $1.2 \& 1.4 \mathrm{ml} / 100 \mathrm{mg}$ body weight) of human placental extract (HPE) was compared with that of control group and standard group.

The percent protection of Test - 2 (HPE 1.2) and Test -3 (HPE 1.4) groups was $100 \%$ and with Test - 1 (HPE 1.0) group was $33.3 \%$ when compared to Control group in pentylenetetrazole induced convulsions in mice. There were no subsequent episodes of seizures and none died in all Test groups and Standard group compared to Control group. There was increase in the time of onset and decrease in the time of duration and recovery from convulsions in Test -1 (HPE 1.0) group compared to control group.

Statistical analysis of Test - 1 (HPE 1.0) group as compared to Control group was highly significant $\mathrm{P}<$ 0.001 .

The results suggest that human placental extract (HPE) has anticonvulsant property.

The mechanism by which pentylenetetrazole produce convulsions, has not been completely understood. Generally accepted mechanism by which pentylenetetrazole exerts its action is by acting as an 
antagonist at the picrotoxin sensitive site of the $\mathrm{GABA}_{\mathrm{A}}$ receptor complex. ${ }^{15}$ Papp et al. found that pentylenetetrazole also increases calcium influx and sodium influx, both of which depolarize the neuron. ${ }^{16}$

Another mechanism suggested by other studies has demonstrated that oxidative stress might be involved in the pathophysiology of pentylenetetrazole (PTZ) induced epilepsy. ${ }^{17-21}$ Pentylenetetrazole (PTZ) at a convulsant dose decreases antioxidant enzymes activity and glutathione levels and increases lipid peroxidation in brain.

In the present study human placental extract (HPE) has shown significant protection from pentylenetetrazole (PTZ) induced convulsions in mice. The probable anticonvulsant mechanism of action of HPE may be due to its increased antioxidant enzymes (superoxide dismutase and catalase) activity and glutathione levels and decreased lipid peroxidation in brain. ${ }^{22}$

The various other mechanism of action of human placental extract (HPE) as an anticonvulsant may be either due to agonistic action on $\mathrm{GABA}_{\mathrm{A}}$ receptor complex or due to decrease in calcium influx and sodium influxes in neuron, as the mechanism of convulsant action of pentylenetetrazole is related to it. It requires further study to establish the hypothesis.

\section{CONCLUSION}

The present study showed that human placental extract (HPE) possesses anticonvulsant activity against pentylenetetrazole induced convulsions in albino mice. Further studies are required to unearth full potential of human placental extract (HPE) as an anticonvulsant.

\section{ACKNOWLEDGEMENTS}

The authors are thankful to the Principal and Management of Chalmeda Anand Rao Institute of Medical Sciences (CAIMS), Karimnagar, Andhra Pradesh, India, for providing all the necessary facilities to carry out the study.

Funding: None

Conflict of interest: None declared

Ethical approval: Approved by the Institutional Animal Ethics Committee (IAEC)

\section{REFERENCES}

1. James O. McNamara. Pharmacotherapy of the Epilepsies. In: Laurence L. Brunton, Bruce A. Chabner, Bjorn C. Knollmann, eds. Goodman \& Gilman's The Pharmacological Basis of Therapeutics. 12th ed. New York, NY: McGrawHill; 2011: 583-607.

2. Bharucha NE. Epidemiology of epilepsy in India. Epilepsia 2003; 44: 9-11.
3. Gourie-Devi M, Gururaj G, Sathishchandra P, Subbakrishna DK. Prevalence of neurological disorders in Bangalore, India: A community-based study with a comparison between urban and rural areas. Neuroepidemiology 2004; 23: 261-8.

4. Roger J. Porter, Brian S. Meldrum. Anti-seizure drugs. In: Bertram G. Katzung, eds. Basic and Clinical Pharmacology. $11^{\text {th }}$ Edn. New Delhi, Tata McGraw-Hill Education Private Limeted; 2009: 399-422.

5. Brodie M.J., Dichter M. Anti-convulsant drugs. N. Engl. J. Med. 1996; 334: 168-175.

6. Liao WP, Chen L, Yi YH, Sun WW, Gao MM, Su $\mathrm{T}$, et al. Study of antiepileptic effect of extracts from Aconus tatarinowii Schott. Epilepsia 2005; 46: 214.

7. Piyali Datta Chakraborty and Debsish Bhattacharya (2012). Aqueous Extract of Human Placenta, Recent Advances in Research on the Human Placenta, Dr. Jing Zheng (Ed.), ISBN: 978-953-51-01949, InTech, Available from: http://www.intechopen.com/books/ recent-advances-in-research-on-the-human-placenta/ aqueous-extract-of-human-placenta-as-atherapeutic-agent.

8. Shibasaki T, Odagiri E, Shizume K, Ling N. Corticotropin-releasing factor like activity in human placental extracts. J Clin Endocrinol Metab 1982; 55: 384-6.

9. H. Gerhard Vogel, Wolfgang H. Vogel, Berhard Ascholkens, Jurgen Sandow, Gunter Muller, Wolfgang F. Vogel. Drug Discovery and Evaluation, $2^{\text {nd }}$ Edn, Springer Verlag, Berlin, Heidelberg, 2002:422.

10. Sur T. K. et al. Anti-inflammatory and anti-platelet aggregation activity of human placental extract. Acta Pharmacol Sin, 2003 Feb. 24(2) 187-192.

11. Joseph S, David J, Joseph T. Additive anticonvulsant effect of flunarizine and sodium valproate on electroshock and chemoshock induced convulsions in mice. Indian $\mathbf{J}$ Physiol Pharmacol 1998;42:383-8.

12. Ashish K. Rehni, Nirmal Singh. Reversal of pentylenetetrazole - induced seizure activity in mice by Nickel Chloride. Indian J. Pharmacol 2009;41:15-8.

13. Loscher W, Honack D, Fassbender CP, Nolling B. The role of technical, biological and pharmacological factors in the laboratory evaluationof anticonvulsant drugs. III: Pentylenetetrazole seizure models. Epilepsy Res 1991; 8: 171-189.

14. Starzl TE, Niemer WT, Dell M, Forgave PR. Cortical and subcortical electrical activity in experimental seizures induced by metrazole. J Neuropath Exp Neurol 1953; 12: 262-76.

15. Ramanjaneyulu R, Ticku MK. Interactions of pentamethylenetetrazole and tetrazole analogues with the picrotoxinin site of the benzodiazepineGABA receptor-ionophore complex. Eur J Pharmacol 1984;98:337-45. 
16. Papp A, Feher O, et al. The ionic mechanism of the pentylenetetrazole convulsions. Acta Biol Hung 1987;38(3-4):349-61.

17. Erakovic' V, Zupan G, Varljen J, Simonic'. A Pentylenetetrazole-induced seizures and kindling: changes in free fatty acids, superoxide dismutase, and glutathione peroxidase activity. Neurochem Int 2003;42:173-8.

18. Akbas SH, Yegin A, Ozben T. Effect of pentylenetetrazole induced epileptic seizure on the antioxidant enzyme activities, glutathione and lipid peroxidation levels in rat erythrocytes and liver tissues. Clin Biochem 2005;38:1009-14.

19. Armag an M, Kutluhan S, Yilmaz M, Yilmaz N, Bu“lbu"1 M, Vural H, et al. Topiramate and vitamin E modulates antioxidant enzymes, nitric oxide and lipid peroxidation in pentylentetrazole-induced nephrotoxicity in rats. Basic Clin Pharm Toxicol 2008;103:166-70.
20. Frantseva MV, Perez Velazquez JL, Tsoraklidis G, Mendonca AJ, Adamchik Y, Mills LR, et al. Oxidative stress is involved in seizure-induced neurodegeneration in the kindling model of epilepsy. Neuroscience 2000;97:431-5.

21. Deniz Onay B, Tasdemir E, Tümer C, Bilgin HM, Atmaca M. Dose dependent effects of ghrelin on pentylenetetrazole induced oxidative stress in a rat seizure model. Peptides 2008;29:448-55.

22. Shinde V, Dhalwal K, Paradkar AR, Mahadik KR, Kadam SS. Evaluation of in-vitro antioxidant activity of human placental extract. Pharmacology online 2006;3:172-9.

doi:10.5455/2319-2003.ijbcp20131012

Cite this article as: $\mathrm{S}$ Avanthi, Chinnam $\mathrm{p}$, Rao GS, Kumar GSP, Mohsin M. Experimental evaluation of anticonvulsant effect of human placental extract in pentylenetetrazole induced convulsions in mice. Int $\mathbf{J}$ Basic Clin Pharmacol 2013;2:571-6. 